\title{
First report of Fusarium concentricum causing fruit blotch on roselle (Hibiscus sabdariffa)
}

\author{
Abd Rahim Huda-Shakirah ${ }^{1} \cdot$ Kamarudin Nur-Salsabila $^{1} \cdot$ Masratul Hawa Mohd $^{1}$ \\ Received: 12 December 2019 / Accepted: 2 March 2020 / Published online: 12 March 2020 \\ (C) Australasian Plant Pathology Society Inc. 2020
}

\begin{abstract}
Symptoms of fruit blotch were noticed on roselle (Hibiscus sabdariffa) in Relau, Penang and Karangan, Kedah. The aims of this study were to isolate and identify the suspected causal pathogen and to evaluate its pathogenicity towards the host. Two isolates of Fusarium sp. were isolated from the blotched fruits of $H$. sabdariffa and morphologically identified. Sequences analysis based on translation elongation factor (TEF1- $\alpha$ ) and mitochondrial small subunit ribosomal DNA (mtSSU rDNA) showed that both isolates had $99.53 \%$ identity to AF333934 and 100\% to AF333941, Fusarium concentricum. Phylogenetic analysis demonstrated that both isolates were in the same clade with the reference isolates of F. concentricum from GenBank, supported by $97 \%$ bootstrap value. The isolates were pathogenic toward H. sabdariffa, exhibiting typical blotch symptoms on the inoculated fruits. This is the first report of fruit blotch disease caused by F. concentricum on H. sabdariffa in Malaysia.
\end{abstract}

Keywords Hibiscus sabdariffa $\cdot$ Fruit blotch $\cdot$ Fusarium concentricum

Roselle (Hibiscus sabdariffa) belongs to the Malvaceae family. It is an annual herb and woody-based shrub (Nwaukwu and Ataga 2012). Over 300 species of Hibiscus are widely cultivated throughout the world. Roselle is one of the most commonly distributed Hibiscus species in tropical and subtropical regions including Malaysia (Mohamed et al. 2012). However, roselle is susceptible to a number of fungal infections which cause significant losses to farmers by reducing fruit production (Hassan et al. 2014). During preliminary observations in 2018, fruit blotch disease of roselle was noticed in Relau, Penang and Karangan, Kedah. Therefore, this study attempted to isolate and identify fungi associated with blotched fruit of $H$. sabdariffa and to confirm their pathogenicity through assay.

Symptomatic fruit samples were excised and surface sterilized with $70 \%$ ethanol and $1 \%$ sodium hypochlorite $(1 \% \mathrm{NaOCl})$ for $3 \mathrm{~min}$ respectively, and rinsed in sterile distilled water three times consecutively for $1 \mathrm{~min}$ each. The samples were air-dried, transferred onto potato dextrose agar (PDA) and incubated at $25 \pm 2{ }^{\circ} \mathrm{C}$ for 2 to 3 days. Pure cultures obtained from water agar (WA) plates were

Masratul Hawa Mohd

masratulhawa@usm.my

1 School of Biological Sciences, Universiti Sains Malaysia, 11800 Penang, Malaysia used for further analysis. Colony appearance and pigmentation were observed from PDA plates. Carnation leaf agar (CLA) was used to observe the structure of macroconidia, microconidia, conidiogenous cells and sporodochia. The length and width of 30 randomly selected macroconidia and microconidia were measured and recorded.

Approximately $60 \mathrm{mg}$ of fine mycelial powder was extracted using Invisorb Spin Plant Mini Kit (Stratec, Germany) according to the manufacturer's instruction. PCR amplifications of TEF1- $\alpha$ and mtSSU rDNA were carried out using primers pairs of EF1/EF2 (O'Donnell et al. 1998a) and MS1/MS2 (White et al. 1990). The amplification was carried out in a total volume of $50 \mu \mathrm{l} \mathrm{PCR}$ mixture as described by Kee et al. (2017). The PCR reactions for TEF1- $\alpha$ and mtSSU were performed in a MyCycler ${ }^{\mathrm{TM}}$ Thermal Cycler (Bio-rad, Hercules, CA, USA) by following conditions as suggested by Kee et al. (2019) and Laurence et al. (2012), respectively. The PCR fragments were sent to a service provider for DNA purification and sequencing (First BASE Laboratories Sdn Bhd, Seri Kembangan, Malaysia).

The sequences obtained were analyzed and aligned using MEGA7 (Kumar et al. 2016) and BLAST was performed against sequences in the GenBank database (https://blast. ncbi.nlm.nih.gov/). The phylogenetic tree was constructed using maximum likelihood (ML) tree based on Tamura-3parameter model (Tamura 1992) with 1000 bootstrap replications. 
Fig. 1 Morphological characteristics of Fusarium concentricum isolates from fruit blotch of roselle (H. sabdariffa) in Malaysia. a Colony appearance on PDA; b Reverse pigmentation; c Orange sporodochia on CLA; $\mathbf{d}$ Macroconida; e Microconidia; $\mathbf{f}$ Microconidia on false head

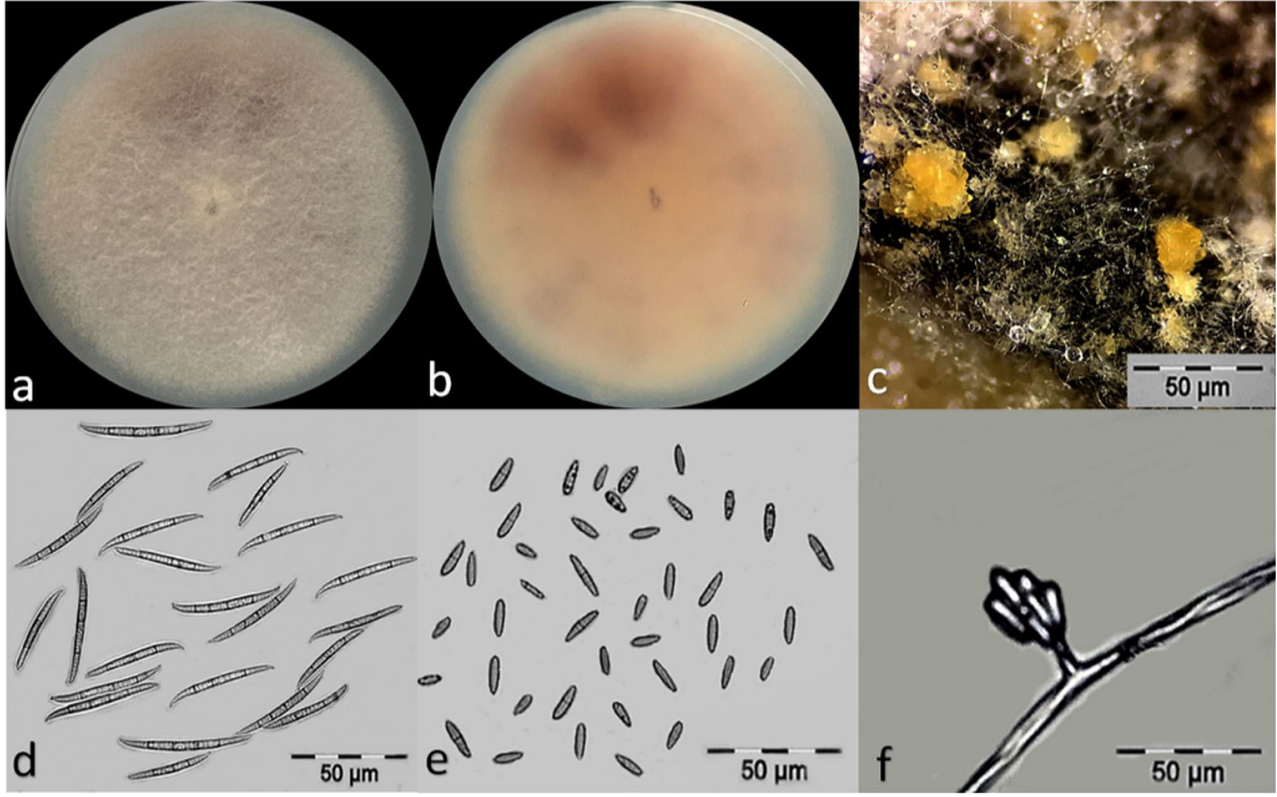

The pathogenicity assay was employed on 12 attached healthy fruits on four plants of $H$. sabdariffa. Fungal mycelial plugs were prepared from 7-day-old PDA cultures using a sterile cork borer (6 $\mathrm{mm}$ diameter) while control plugs were prepared from an empty PDA plate. Two wound points were made for each fruit, one for treatment and one for control. Both fungal mycelia and control plugs were aseptically inoculated on each fruit using a sterilized forcep and the plugs were covered with wet cotton to retain moisture. Each fungal isolate was tested in triplicate and the test was done twice. The

Table 1 GenBank accession numbers of F. concentricum and other Fusarium spp. used in the phylogenetic analysis

\begin{tabular}{|c|c|c|c|c|c|c|}
\hline \multirow[t]{2}{*}{ Species } & \multirow[t]{2}{*}{ Isolate } & \multirow[t]{2}{*}{ Host } & \multirow[t]{2}{*}{ Locality } & \multicolumn{2}{|c|}{$\begin{array}{l}\text { GenBank accession } \\
\text { No. }\end{array}$} & \multirow[t]{2}{*}{ References } \\
\hline & & & & TEF $1-\alpha$ & mtSSU & \\
\hline Fusarium concentricum & NRRL29943 & $\begin{array}{l}\text { Soil of Pinus densiflora } \\
\text { forest }\end{array}$ & Japan, Tsukuba, Ibaraki & AF333934 & AF333942 & Aoki et al. 2001 \\
\hline F. concentricum & NRRL26434 & Oryza sativa & Japan, Tsukuba, Ibaraki & AF333933 & AF333941 & Aoki et al. 2001 \\
\hline F. concentricum & NRRL29944 & Oryza sativa & Japan, Tsukuba, Ibaraki & AF333935 & AF333943 & Aoki et al. 2001 \\
\hline F. concentricum & NRRL 25303 & Oryza sativa & Japan, Tsukuba, Ibaraki & AF160283 & U61614 & Aoki et al. 2001 \\
\hline F. concentricum & NRRL25181 & Musa sapientum & Costa Rica & AF160282 & U61600 & $\begin{array}{l}\text { O’Donnell et al. } 1998 \mathrm{~b} \text {; Nirenberg } \\
\text { and O'Donnell } 1998\end{array}$ \\
\hline F. concentricum & FS3 & Hibiscus sabdariffa & Penang, Malaysia & MN384965 & MN384966 & Present study \\
\hline F. concentricum & FS32 & Hibiscus sabdariffa & Kedah, Malaysia & MN384967 & MN384968 & Present study \\
\hline Fusarium proliferatum & MUCL31970 & Spanish forest soil & Canary Island & AF336913 & AF336911 & Kwon et al. 2001; Anderson et al. 2005 \\
\hline F. proliferatum & NRRL31071 & $\begin{array}{l}\text { Triticum aestivum } \mathrm{cv} \text {. } \\
\text { super dwarf }\end{array}$ & USA & AF291058 & AF291056 & Kwon et al. 2001; Anderson et al. 2005 \\
\hline Fusarium fujikuroi & NRRL13566 & Oryza sativa & Taiwan & AF160279 & U34499 & O'Donnell et al. $1998 \mathrm{~b}$ \\
\hline Fusarium fractiflexum & NRRL28853 & Cymbidium sp. & Japan, Hiroshima & AF333931 & AF333939 & Aoki et al. 2001 \\
\hline F. fractiflexum & NRRL28854 & Cymbidium sp. & Japan, Komoro, Nagano & AF333932 & AF333940 & Aoki et al. 2001 \\
\hline Fusarium sacchari & NRRL13999 & Saccharum officinarum & India & AF 160278 & U34498 & Li-sha et al. 2017 \\
\hline Fusarium subglutinans & NRRL22016 & Zea mays & United States & AF160289 & U34501 & O'Donnell et al. $1998 \mathrm{~b}$ \\
\hline Fusarium verticillioides & NRRL28893 & Musa cavendishii & Mexico & AF273312 & AF273305 & Hirata et al. 2001 \\
\hline Fusarium nygamai & NRRL 13448 & Sorghum bicolor & Australia & AF160273 & U34510 & Scauflaire et al. 2011 \\
\hline Fusarium oxysporum & NRRL 25356 & Soil & France & AF008480 & AF008446 & O’Donnell et al. $1998 \mathrm{~b}$ \\
\hline Fusarium circinatum & NRRL 29945 & Pinus luchuensis & Japan, Amami, Ohshima & AF333930 & AF333938 & Aoki et al. 2001 \\
\hline Fusarium guttiforme & NRRL22945 & Ananas comosus & South America & AF 160297 & U34504 & $\begin{array}{l}\text { Nirenberg and O'Donnell 1998; } \\
\text { O’Donnell et al. } 1998 \mathrm{~b}\end{array}$ \\
\hline Fusarium hostae & NRRL29647 & Hyacinthus sp. & The Netherlands & AF324327 & AF324288 & Baayen et al. 2001 \\
\hline Fusarium incarnatum & CBS132907 & Triticum sp. & Iran & MN170477 & MH979695 & Xia et al. 2019 \\
\hline
\end{tabular}


Fig. 2 Maximum likelihood (ML) tree of Fusarium concentricum isolates (in bold) from fruit blotch of roselle $(H$. sabdariffa) in Malaysia and other Fusarium spp. generated based on combined dataset of TEF $1-\alpha$ and mtSSU DNA sequences.

Fusarium incarnatum is used as an outgroup. Bootstrap values $(>85 \%)$ are displayed at the nodes and the number of substitutions per position is displayed in the scale bar

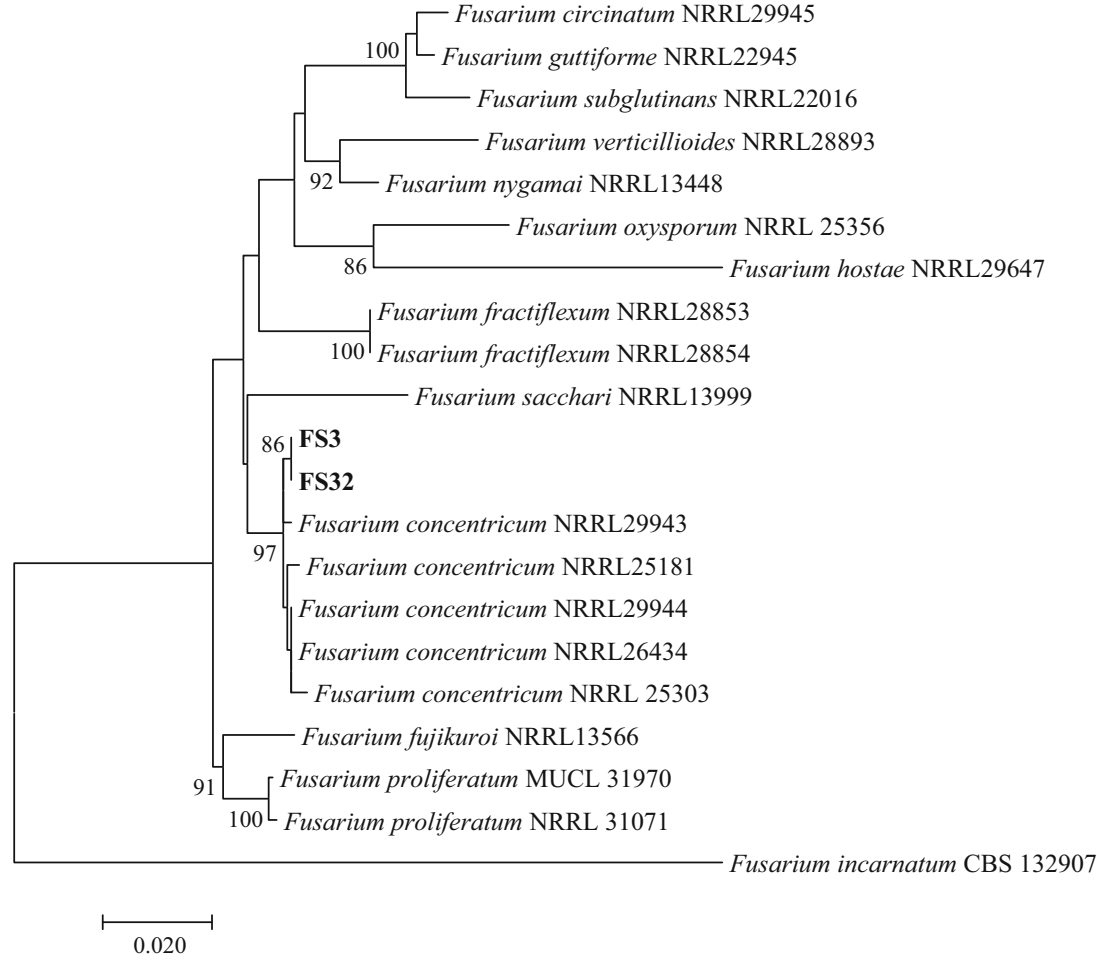

inoculated plants were placed in a plant house at the School of Biological Sciences, USM and incubated at 26 to $32{ }^{\circ} \mathrm{C}$ for 14 days. The disease signs and symptoms were looked for and noted every day. Fungal re-isolation was done from the symptomatic inoculated fruits and the resulting fungal isolates were re-identified morphologically.

Two isolates of Fusarium sp. (FS3 and FS32) were isolated from the blotched fruits of $H$. sabdariffa. Both isolates had pale orange to slightly velvety colonies on PDA plates (Fig. 1a) and pale orange with alternating velvet concentric rings on the reverse side (Fig. 1b). Formation of orange sporodochia was observed on CLA (Fig. 1c). Macroconidia were long, thin walled, 3-5 septate, with a sharp apical cell and foot-shaped basal cell, and were $46.3 \pm 6.8 \times 3.0 \pm 0.6 \mu \mathrm{m}$ in size (Fig. 1d). Microconidia were 0-1 septate, oval shaped,
$9.4 \pm 1.5 \times 3.3 \pm 0.7 \mu \mathrm{m}$ in size (Fig. 1e) and commonly formed in false heads (Fig. 1f). The conidiogenous cells were monophialides and polyphialides. Chlamydospores were absent. The isolates of the present study were presumed to be Fusarium concentricum in accordance with the description by Nirenberg and O'Donnell et al. (1998a) and Leslie and Summerell (2006). Both isolates of $F$. concentricum (MN384965- MN384968) were deposited in the Culture Collection Unit, Department of Plant Pathology, School of Biological Sciences, Universiti Sains Malaysia.

In the BLAST search, isolates FS3 and FS32 were $99.53 \%$ and $100 \%$ similar to the reference sequences of Fusarium concentricum AF333934 (TEF1- $\alpha$ ) and AF333941 (mtSSU), respectively. Resultant sequences were deposited in Genbank as accession numbers, MN384965 and
Fig. 3 Pathogenicity assay of Fusarium concentricum isolates on healthy fruits of roselle (H. sabdariffa). a Irregular necrotic brown lesion developed on the inoculated fruit; $\mathbf{b}$ Presence of orange sporodochia and white mycelia on the lesion surface; c Control fruit remained healthy

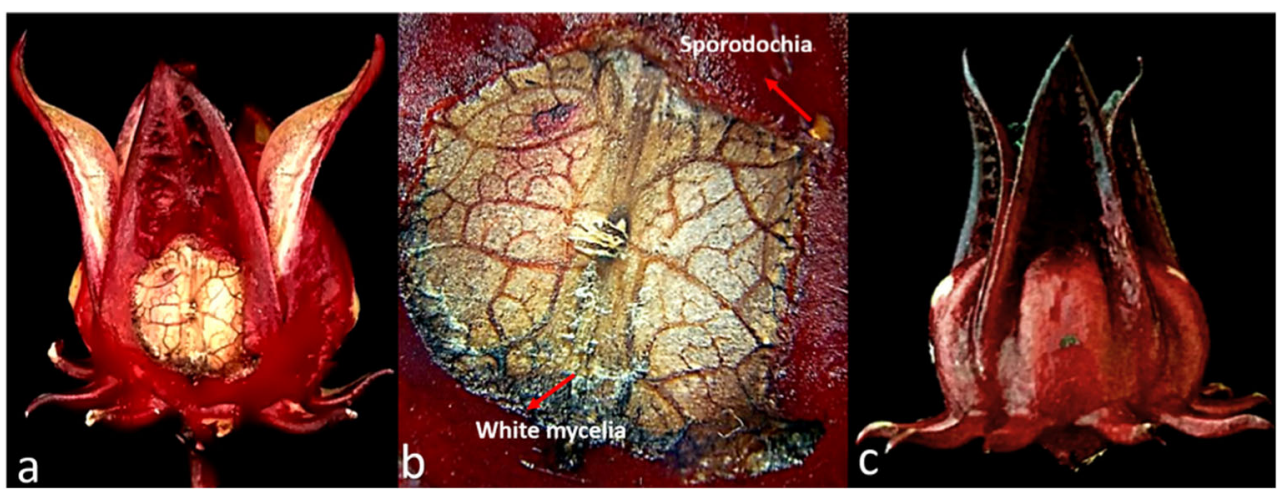


MN384967 for TEF1- $\alpha$ and MN384966 and MN384968 for mtSSU. Several reference sequences of $F$. concentricum and other Fusarium spp. from GenBank used in the phylogenetic analysis are listed in Table 1. The maximum likelihood (ML) tree of the combined dataset of TEF $1-\alpha$ and mtSSU sequences demonstrated that the recovered isolates (FS3 and FS32) clustered in the one clade with the reference isolates of F. concentricum from GenBank, supported by $97 \%$ bootstrap value (Fig. 2). On the basis of morphological characteristics, DNA sequences and phylogenetic analysis, the identity of FS3 and FS32 isolates was confirmed as F. concentricum.

Both FS32 and FS3 isolates were pathogenic toward fruits of $H$. sabdariffa. After 7 days of the pathogenicity assay, the inoculated fruits displayed symptoms of irregular brown necrotic lesions at the wound points. As the disease progressed, the lesions became sunken, enlarged, and turned to darker brown, resulting in the appearance of blotch symptoms (Fig. 3a). The formations of white mycelia and orange sporodochia were observed on the lesion surface 12 days after inoculation (Fig. 3b) whilst the control produced no symptoms (Fig. 3c). Koch's postulates were fulfilled as the same fungal species were successfully re-isolated from the symptomatic inoculated fruits and morphologically re-identified.

Fusarium concentricum was first described by Nirenberg and O'Donnell et al. (1998a) from bananas in Central America and aphids in Korea. This pathogen has a wide host range, associating with multiple diseases on different hosts such as stem rot of Paris polyphylla var. chinensis and fruit rot of pepper and banana (Wang et al. 2013; Abd Murad et al. 2017; Xiao et al. 2019). The present study showed that F. concentricum was a causal pathogen of fruit blotch of roselle. Horst (2013) defined blotch as irregular or indefinite large or small necrotic areas on fruit, having intermediate symptoms between blight and spots. The described symptoms are in accordance with the symptoms displayed on the inoculated roselle fruits. Several different pathogens have been reported to threaten roselle cultivation worldwide and in Malaysia (Ooi and Salleh 1999; Swart and Langenhoven 2000; Amusa et al. 2001; McClintock and Tahir 2004; Ploetz et al. 2007; Eslaminejad and Zakaria 2011; Ansari et al. 2013; Pain et al. 2019).

Accurate identification of a fungal pathogen is crucial for implementing an effective disease management strategy. Morphological features are commonly used to identify fungi, a cost-effective and easy approach (Schmit and Lodge 2004). Nonetheless, the existence of overlapping morphological features between closely related species may lead to the misinterpretation of fungal identification. According to Leslie and Summerell (2006), F. concentricum has similar aerial microconidia which form in a false head as produced by F. circinatum, F. guttiforme, F. sacchari, F. subglutinans and $F$. oxysporum. However, based on a ML tree of combined dataset of TEF $1-\alpha$ and mtSSU genes, isolates of
F. concentricum in the present study were phylogenetically different from those Fusarium species. The TEF1- $\alpha$ gene was selected for phylogenetic analysis because it consists of informative sequences and non-orthologous copies which can distinguish isolates of Fusarium to species level (Geiser et al. 2004; Singh and Gupta 2017). In addition, the mtSSU gene has been widely used as an alternative to accurately delineate the identity of the Fusarium species (Bruns and Szaro 1992).

To our knowledge, this is the first report of $F$. concentricum causing fruit blotch on $H$. sabdariffa in Malaysia. The insights gained from this study can help to understand the disease etiology and further permit formulation of an integrated disease management to limit the disease.

Acknowledgements This work was supported by Research University Grant (1001/PBIOLOGI/8011061) from Universiti Sains Malaysia.

\section{Compliance with ethical standards}

Conflict of interest On behalf of all authors, the corresponding author states that there is no conflict of interest.

\section{References}

Abd Murad NB, Mohamed Nor NM, Shohaimi S, Mohd Zainudin NA (2017) Genetic diversity and pathogenicity of Fusarium species associated with fruit rot disease in banana across peninsular Malaysia. J Appl Microbiol 123:1533-1546

Amusa NA, Kogbe JO, Ajibade SR (2001) Stem and foliar blight in roselle (Hibiscus sabdariffa L. var. sabdariffa) in the tropical forest region of South-Western Nigeria. J Hortic Sci Biotechnol 76:681684

Anderson AJ, Kwon SI, Carnicero A, Falcón MA (2005) Two isolates of Fusarium proliferatum from different habitats and global locations have similar abilities to degrade lignin. FEMS Microbiol Lett 249: $149-155$

Ansari M, Eslaminejad T, Sarhadynejad Z, Eslaminejad T (2013) An overview of the roselle plant with particular reference to its cultivation, diseases and usages. Eur J Med Plants 3:135

Aoki T, O'Donnell K, Ichikawa K (2001) Fusarium fractiflexum sp. nov. and two other species within the Gibberella fujikuroi species complex recently discovered in Japan that form aerial conidia in false heads. Mycoscience 42:461-478

Baayen RP, O'Donnell K, Breeuwsma S, Geiser DM, Waalwijk C (2001) Molecular relationships of fungi within the Fusarium redolensF. hostae clade. Phytopathology 91:1037-1044

Bruns TD, Szaro TM (1992) Rate and mode differences between nuclear and mitochondrial small-subunit rRNA genes in mushrooms. Mol Biol Evol 9:836-855

Eslaminejad T, Zakaria M (2011) Morphological characteristics and pathogenicity of fungi associated with roselle (Hibiscus sabdariffa) diseases in Penang, Malaysia. Microb Pathog 51:325-337

Geiser DM, Jimenez-Gasco M, Kang S, Makalowska I, Veeraraghavan N, Ward TJ, Zhang N, Kuldau GA, O'Donnell K (2004) FUSARIUM-ID v. 1.0: a DNA sequence database for identifying Fusarium. Eur J Plant Pathol 110:473-479

Hassan N, Shimizu M, Hyakumachi M (2014) Occurrence of root rot and vascular wilt diseases in roselle (Hibiscus sabdariffa L.) in upper Egypt. Mycobiology 42:66-72 
Hirata T, Kimishima E, Aoki T, Nirenberg HI, O’Donnell K (2001) Morphological and molecular characterization of Fusarium verticillioides from rotten banana imported into Japan. Mycoscience 42:155-166

Horst RK (2013) Blotch diseases. In: Westcott's Plant Disease Handbook. Springer, Dordrecht

Kee YJ, Suhaimi NN, Zakaria L, Mohd MH (2017) Characterisation of Neoscytalidium dimidiatum causing leaf blight on Sansevieria trifasciata in Malaysia. Aust Plant Dis Notes 12:60

Kee YJ, Zakaria L, Mohd MH (2019) Lasiodiplodia species associated with Sansevieria trifasciata leaf blight in Malaysia. J Gen Plant Pathol 85:66-71

Kumar S, Stecher G, Tamura K (2016) MEGA7: molecular evolutionary genetics analysis version 7.0 for bigger datasets. Mol Biol Evol 33: 1870-1874

Kwon SI, Dohlen CD, Anderson AJ (2001) Gene sequence analysis of an opportunistic wheat pathogen, an isolate of Fusarium proliferatum. Can J Bot 79:1115-1121

Laurence MH, Burgess LW, Summerell BA, Liew EC (2012) High levels of diversity in Fusarium oxysporum from non-cultivated ecosystems in Australia. Fungal Biol 116:289-297

Leslie JF, Summerell BA (2006) The Fusarium laboratory manual. Blackwell Publishing, Ames

Li-sha Z, Zhi-bo Z, Shun L, Ling X, Zhi-ping D, Gui-yuan H, Cai-xian D, Jin-pei M, Jian-kun Z (2017) Identification of pathogen causing rhizome rot of lotus (Nelumbo nucifera) based on morphology and multi-gene sequence analysis. Acta Phytopathol Sin 47:162-173

McClintock NC, Tahir IME (2004) Hibiscus sabdariffa L. In: Grubben GJH, Denton OA (eds) Vegetables/Legumes. PROTA, Wageningen

Mohamed BB, Sulaiman AA, Dahab AA (2012) Roselle (Hibiscus sabdariffa L.) in Sudan, cultivation and their uses. Bull Environ Pharmacol Life Sci 1:48-54

Nirenberg HI, O'Donnell K (1998) New Fusarium species and combinations within the Gibberella fujikuroi species complex. Mycologia 90:434-458

Nwaukwu IA, Ataga AE (2012) Fungi associated with Hibiscus sabdariffa Linn (Yakwa) seed from plateau state. Scientia Africana 11:125-129

O’Donnell K, Kistler HC, Cigelnik E, Ploetz RC (1998a) Multiple evolutionary origins of the fungus causing Panama disease of banana: concordant evidence from nuclear and mitochondrial gene genealogies. Proc Natl Acad Sci U S A 95:2044-2049
O’Donnell K, Cigelnik E, Nirenberg HI (1998b) Molecular systematics and phylogeography of the Gibberella fujikuroi species complex. Mycologia 90:465-493

Ooi KH, Salleh B (1999) Vegetative compatibility groups of Fusarium oxysporum, the causal organism of vascular wilt on roselle in Malaysia. BIOTROPIA SE J Trop Biol 12:31-41

Pain NA, Weir BS, Burgess LW, Phanthavong S, Balmas V, Schneider M (2019) First report of Coniella hibisci causing leaf and stem canker in the Lao P.D.R. Aust Plant Dis Notes 14:18

Ploetz RC, Palmateer AJ, Geiser DM, Juba JH (2007) First report of Fusarium wilt caused by Fusarium oxysporum on roselle in the United States. Plant Dis 91:639

Scauflaire J, Gourgue M, Munaut F (2011) Fusarium temperatum sp. nov. from maize, an emergent species closely related to Fusarium subglutinans. Mycologia 103:586-597

Schmit JP, Lodge DJ (2004) Classical methods and modern analysis for studying fungal diversity. In: Dighton J, White J, Oudemans P (eds) The fungal community; its organization and role in the ecosystem, 3rd edn (mycology volume 3). CRC Taylor \& Francis, Boca Raton, pp 193-214

Singh BP, Gupta VK (2017) Molecular markers in mycology. Springer International Publishing Switzerland, Cham

Swart L, Langenhoven P (2000) First report of Botrytis blight caused by Botrytis cinerea on Hibiscus in South Africa. Plant Dis 84:487

Tamura K (1992) Estimation of the number of nucleotide substitutions when there are strong transition-transversion and $\mathrm{G}+\mathrm{C}$-content biases. Mol Biol Evol 9:678-687

Wang JH, Feng ZH, Han Z, Song SQ, Lin SH, Wu AB (2013) First report of pepper fruit rot caused by Fusarium concentricum in China. Plant Dis $97: 1657$

White TJ, Bruns T, Lee SJWT, Taylor JL (1990) Amplification and direct sequencing of fungal ribosomal RNA genes for phylogenetics. In: Innis MA, Gelfand DH, Sninsky JJ, White TJ (eds) PCR Protocols: a guide to methods and applications. Academic, San Diego, pp 315322

Xia JW, Sandoval-Denis M, Crous PW, Zhang XG, Lombard L (2019) Numbers to names-restyling the Fusarium incarnatum-equiseti species complex. Persoonia 43:186-221

Xiao RF, Wang JP, Zheng MX, Su HL, Zhu YJ, Liu B (2019) First report of Fusarium concentricum causing stem rot disease on the medicinal plant Paris polyphylla var. chinensis in China. Plant Dis 103:1418 